\title{
The Double Consciousness in The Color Purple
}

\author{
LUO Jian-ting \\ Sichuan University of Arts and Science, Dazhou, China
}

\begin{abstract}
The Color Purple was written by the famous author Alice Walker. In the novel the author Alice Walker creates several characters to illustrate the black people's struggle in the white-dominated mainstream society. This paper focuses on the main characters in The Color Purple to explore their own identities and arouse the sense of their ethnic pride, and also attempts to answers how to overcome such distressed "duality" of black soul and how to get the fullness of the soul in the modern society.
\end{abstract}

Keywords: double consciousness, humanity, cultural identity, ethnic

\section{Introduction}

Alice Walker is an outstanding black woman writer in contemporary American literary world. She published a large number of works about black women's struggle for political, economic, gender, and racial equality. In 1982, Alice Walker published the novel The Color Purple. In 1983, it won the three highest honor awards in the American literature: the Pulitzer Prize, the National Book Award, and the National Association of Reviewers Award. In 1985, famous director Steven Spielberg made it into a film, which made Walker popular in her hometown. What is more, The Color Purple has become famous in the African American literature and women literature in the university. This novel is about the protagonist Celie's tragic pathos story. Celie's mother is seriously ill, and her sister is still young. After her mother's death, Celie is forced to marry a widower, who builds her seriously tragedy. Writing letters to her sister and god is the only way to express her inner loneliness and pain. With her sister, Sophie and Shug's help, finally she turns into an independent black woman. In this famous work, Walker creates a few different bright and colorful personalities.

\section{The Color Purple and The Souls of Black Folk}

Alice was born in a poor peasant family, Georgia, in the southern USA. The poor childhood and the political movement experience gave her a strong sense of mission and sense of responsibility. She said,

Because I'm black, I'm a woman, I grew up in poverty, I am a southerner, my view of the world is very different from many people view of the world. I can help people understand the view of the thing what needs to change. (Davis, 1989, p. 26)

She puts racial equality and women's liberation as a lifelong career. Her works were mostly set in her familiarity with Georgia and Mississippi countryside as the background of the American south. Her novels mainly reflect black people especially effected by the social dual stress of black women and black men, love and 
hate, and show the struggle of their pursuit of self liberation and complete personality. Her work is focused on the struggles of black people, particularly women, and they live in a violent society.

The Color Purple happens in the early 20th century to the eve of the second world war, and the background is the southern rural Georgia, and it is about a story of two sisters - one a missionary in Africa and the other a child wife living in the South - who prove their loyalty to and trust in each other across time, distance, and silence. As black women, they have to face the harsh reality, but they can company with each other. However, Celie is forced to marry a black man Albert, who looks down upon her, and he loves Shug very much. Nettie is Celie's sister. Albert attempts to rape her and dislodges her away so that she has to go to Africa. Shug is Albert's love. She is never afraid of her female identity. She encourages Celie to leave Albert, and set up a tailor shop. At the end of the story, Celie and Nettie reunite together. It also shows the important cultural background of the development of female of black Africa civilization. As Barbara Christian claims, "The Color Purple is a book that emphasizes the oppression of black women by black men" (Harold, 1989, p. 52). "Celie is an example of a male-dominated and abused woman" (Harold, 1989, p. 35).

Du Bois is an American civil rights leader and writer. He used the "veil" to describe the ethnic between the white and black, also explained the inner conflict in the white and black American by "double consciousness".

Black was born with a veil, in this the world endowed with insight - this is a kind of no real self consciousness, but merely through another world scale to measure the feeling of his own soul. It is a strange feeling, this is a double consciousness, a kind of always through the view of themselves, others with another world scale to measure the feel of his soul. (Dubois, 1994, p. 12)

In other words, double consciousness reflects the blacks in the black culture and white mainstream culture, and two different cultures view generated by a state of psychological conflict. This explanation in The Souls of Black Folk had a larger effect for aspiring young black intellectuals.

As early as 1897 Du Bois first published an article in the Atlantic Monthly about "double consciousness" concept, and after a slight changes in form, he published a book named The Souls of Black Folk, which further explained the concept of "double consciousness" in the blacks' experience that black felt their duality: Both Americans and black, therefore, in his black skin wrapped body there are two souls, two thoughts, two mixed up and understanding of the fighting spirit. African American history is such a struggle history, namely: Making the desire of getting conscious human dignity and the dualism become one, so that they can be a better, more real self. He would not let black soul bleach in the flow of white Americans' thought culture, because he knew that "the black blood flowing a information to the entire world" (Dubois, 1994, p. 56). Double consciousness reveals the complicated relationships between the black culture and the white culture.

Double consciousness in The Souls of Black Folk has influenced the black people greatly. These make them think about how to explore their own culture and find the best way they live in the white world. Blacks face the great challenge of identity when the white culture is the mainstream culture. For blacks' identity, this duality has brought great trouble and confusion. In other words, black Americans survive in the cracks of dislocation of black and white culture conditions and cultural mentality. Walker once said: "we are in the same nation, a nation does not reject their spirit. If rejected, for the sake of our children, we as artists, and the future of witness's responsibility is to pick them up" (Washington, 1979, p. 135). And American black culture can keep vitality in 
the interaction. The Color Purple can well illustrate the double consciousness of the black people.

\section{The "Double Consciousness" in The Color Purple}

\section{Nettie's Double Consciousness}

In The Color Purple, Nettie is one of the main characters - Celie's sister. She is more beautiful than Celie, who is brave and gets some education. She has been in the fight against the fate. She escapes from the house and visits her sister. Because of the harassment of Mr. X, she resolutely resists and runs away to the black pastor Samuel's home and gets a job as a servant, and then they go to Africa as a missionary. In Africa where it has connection of her black skin, they have many unique experiences. Despite there are lots of difficulties and unfortunate events, with their tenacious black national spirit they are able to overcome eventually. As a black American, she has some different feelings about this place.

She never thinks about it as a real place. In her mind, she is an American, and as an American, she would not go a place overrun with savages who do not wear clothes. Because of her black consciousness, as she writes in the letter:

In the morning I started asking questions about Africa and started reading all the books Samuel and Corrine have on the subject. Did you know there were great cities in Africa, greater than Milledgeville or even Atlanta, thousands of years ago? That the Egyptians who built the pyramids and enslaved the Israelites were colored? That Egypt is in Africa? That the Ethiopia we read about in the Bible meant all of Africa? (Walker, 1983a, p. 136)

After knowing all about Africa, she begins to realize that Africa is unique and great. She does not know anything about Africa, so it makes her remain largely in the thirst for knowledge. When she really begins to accept education herself, she incredibly exclaims "there are colored people in the world who want us to know. Want us to grow and see the light!" (Walker, 1983a, p. 159). The black couple make her feel proud as a black. However, as a black grew up in the USA, in her mind she still has a strong white human characteristic. "I read where the Africans sold us because they loved money more than their own sisters and brothers. How we were made to work" (Walker, 1983a, p. 147). She has a little resentment and anger about these. In the letter she describes where the Negro is still suffering the unfair treatment, the cruel plunder of white to black and women don't have freedom, especially girls wouldn't accept education and so on. Black Africans encounter the black American racial oppression of the projection to a greater racial background of suffering, which makes it become the third world.

As a pious missionary in Africa, Nettie is idealistic; what is more, she has a kind of superior white consciousness. She believes that it is of great importance to educate Olinka girls and women in Africa for the sake of African women's enlightenment and independence. Nettie writes in her letter: "The Olinka do not believe girls should be educated, when I asked a mother what she thought of this, she said: A girl is nothing to herself; only to her husband can she become something" (Walker, 1983a, p. 235). Consequently, Nettie spends most of her time educating the Olinka children and persuades the parents to let their girls take education. Nettie's experiences in Africa mentions that the local people live in traditional, peaceful, and happy life. Later, whites build roads in their lands, and occupy the home of indigenous people who have lived from generation to generation. They demolish houses and occupy lands, also destroy forest. They make Olinca into a rubber plantation, and force the local people to buy iron roof. They even force them to pay the land tax and water tax. Samuel and Nettie go to the 
Britain church for help, but they are ignored and insulted by them. When they return to Africa, local people disappointed them, and they have to go to the encampment where someone lives in the forest against white people. This is a journey of roots. It also reveals blacks all over the world under the oppression of racism. They need to rely on each other and support each other to know themselves and get rid of mental slavery to obtain independent personality.

\section{Celie's Black Consciousness and Identity}

Black women cannot discover their female beauty and value, lose self-respect and dignity, and thus lose their female identity. "Identity gives us a sense of who we are and to some extent satisfies a demand for some degree of stability and of security. Crises occur when an identity position is challenged or becomes insecure" (Woodward, 2002, p. xi). In this novel, the exploration of female identity refers to the rediscovery of black female's particularity. Celie is the protagonist in the novel. She does not have self-esteem, status, ideal, and pursuit. She is a gentle and virtuous black girl. However, when she is 14 , she is raped by her stepfather. Later, her stepfather bargains with Mr. X, and orders her to marry Mr.X like an item. In the men's eyes, woman is an object of males which can be abused, and even sold on the cheap price. She comforts herself: "I took out a Shug's photos. I looked at her eyes. Her eyes said, yes, sometimes it is the way" (Walker, 1983a, p. 57). As a black American woman, her black nature is still buried in the blood, and waits to be awakened. In colonial economic, political, and cultural invasion, the black is surely the inferior people. "Black women are the most oppressed people in the world" (Gates \& Appiah, 1993, p. 39). In order to get rid of this kind of inferiority and self-destruction, the blacks can get real life-changing opportunity.

In her tragic life, there are two important people to help her find herself and awaken Celie's black consciousness. Here Alice Walker puts an emphasis on the significance of black sisterhood and she believes that she "sees the possibility of empowerment for black women if they create a community of sisters that can alter the present-day unnatural definition of woman and man" (Christian, 1985, p. 181). Nettie is a very important people. Nettie's letters have three important effects on Celie. First, Celie can begin to respond and be changed by Nettie's history and experience. Second, she is released from the guilt of incest when she learns "Pa is not our Pa" (Walker, 1983a, p. 254). Third, Celie could be able to implement her own variety of narrative strategy when she moves from directly. Therefore, Nettie's letters from Africa help both Nettie and Celie grow mature emotionally and psychologically. In Celie's unfortunate marriage and miserable life, Nettie's letters bring her comfort and ease her suffering. Her encouragement makes her live bravely, and makes her think everything will be OK.

The other important role in the growth of Celie is Shug. She is a black woman who dares to love, hate, say, and be a black woman. What is more, she has a very strong sense of herself. And she always stays strong independent consciousness, which plays an enlightening role in Celie's personal feelings, also lets she understand her own emotional needs. She even educates Celie to respect herself, to know her talents, and to set up her own confidence. She tells Celie "God of the bible is white, and a man. Don't listen to you (women)" (Walker, 1983a, p. 228), and she believes that "God is inside you and inside everybody else. You come into the world with God" (Walker, 1983a, p. 229). In other words, people can find their life road by believing in themselves first. She encourages Celie that she should believe in herself, to look for spiritual strength during having fun in life. Finding their own God in harmony with nature, loving life, enjoying life, treating people with love and being loved are the 
best way to worship God. Because of Shug, she finally breaks the silence of many years and announces to leave home to find a new life. Celie overcomes hatred of her body. For the first time, she feels as a black American's dignity, and starts to know herself. She also realizes as a black woman she should enjoy the happiness. As a result, Celie finds her American black women's identity. She is full of confidence, dignity, and personality of female independence. Her black consciousness gets stronger than before and "she takes a crucial step in developing her concept of self through her business, her love for Shug, her dreams about her own home, visualizing new spaces - physical and spiritual for herself" (Linda, 1994, p. 123).

\section{Sofia's Black Consciousness Against the White}

Sophia is the wife of Celie's stepson Harpo. She is "clear medium brown skin, gleam on it like on head in a mass of plaits. She not quiet as tall as Harpo but much bigger, and strong and ruddy looking, kike her mama brought her up on pork" (Walker, 1983a, p. 28). Her father does not agree on the marriage, so she becomes pregnant and forces his father to agree. Sophia insists on the freedom of marriage. Sophia is diligent and hard working, but her husband always wants her to be obedient to him. They always fight and Sophia wins every time. When Sophia knows Celie has advised Harpo to hit her, she says to her angrily "All my life I had to fight. I had to fight my daddy. I had to fight my brothers. I had to fight my cousins and my uncles" (Walker, 1983a, p. 65). Celie agrees that males oppress females and lack of defiance, however, Sophia has the spirit of revolt.

She not only fights for herself against the blacks, but also fights against the whites. After she devoices with Harpo, she stays with a boxer. They walk in the street and meet the Miss Millie, the mayor's white wife. She thinks their kids are very lovely, so that she asks Sophia to be their maid. However, Sophia refuses to be a maid in the major's family. The mayor beats her so that Sophia knocks down the major. Sophia fights against the whites.

They crack her skull, they crack her ribs. They tear her nose loose one side. They blind her in one eye. They blind her in one eye. She swung from head to foot. Her tongue the size of my arm, it sticks out between her teeth like a piece of rubber. She can't talk. And she just about the color of an eggplant. (Walker, 1983a, p. 97)

Sophia is sentenced in prison for 12 years. She becomes an unquestioning captive, and becomes the most disciplined one in the prison, which makes others not even believe that she is the one who talks back to the mayor wife.

It seems Sophia has completely lost her belligerence and been tamed. However, in her inner heart, "I dream of want to kill, whether awake or asleep, I want to kill people” (Walker, 1983a, p. 175), and this is Sophia's most intense mental activity. Under the cruel torture of white policeman, she is still stubborn alive, and her yielding is temporary. "For the problem of the Twentieth Century is the problem of the color-line" (Walker, 1983b, p. 7). But in a black whole country, a black women's resistance is weak and despaired. Sophia is not feeling down. She is optimistic and tenacious. She thinks more rational ways about the problem of the relationship between the white and black. Sophia's greatest progress is from thinking about the destiny of the individual and the destiny of the black race. She knows the fist cannot solve all problems, and thinking can make us take more rational actions. Sophia's revolting spirit arouses their national consciousness and the characteristics of the black consciousness. She does not succumb to tyranny and oppression, and still refuses to become a victim of gender and racial oppression. Walker once said Sophia's name is named after the goddess of wisdom, because it is the goddess of wisdom, no matter how painful, she will defend herself and no matter how much time the tongue bounded by 
white people, she still has her own laughter and speech. Sophia's experience tells us that an American with double consciousness is not blindly punched out, but in harmony with two nations, which has to do with Du Bois in The Souls of Black Folk.

\section{Conclusion}

Alice walker is a famous author in contemporary American literature. She is famous for her portrayal of the life and struggle of black people, especially black women. This novel implies to us the double consciousness on the part of blacks, and explores self identity and awakes the blacks national consciousness. They learn how to love themselves and face what they had in spite of those changes. All the family members are passionate, and they respect and appreciate each other very much. And they establish the connection with the African blacks and win the identity, and they also establish the relationship between power and national spirit. The novel explores blacks' own identity and arouses the sense of their ethnic pride.

In The Color Purple, All the characters, male or female, without exception, undergo all kinds of changes, experience a painful learning process, and finally lead a new life and grow up to whole beings. Alice Walker shows her hope in the liberation of black women. She also shows her hope in the transformation of blacks. In this book, nobody gives up, and they always inherit and develop their spirit, and try to behave more excellent than before. Celie is the black victim, who is focused on the point of racial discrimination and gender discrimination. Nettie is an admirer of the white culture; she is also the representative of white black women who acts as a white American woman; however, Sophia tells us the real American blacks should keep black ethnic culture and blend with white people.

\section{References}

Christian, B. (1985). Black feminist criticism. New York: Pergamon Press.

Davis, T. M. (1989). Walker's celebration of self in southern. New York: Chelsea House Publishers.

Dubois, W. E. B. (1994). The souls of Black Folk. New York: Dover Publications.

Gates, H. L., \& Appiah, K. A. (1993). Alice Walker: Critical perspectives past and present. New York: Amistad Press.

Harold, B. (1989). Alice Walker: Modern critical views. New York \& Philadelphia: Chelsea House Publishers.

Linda, T. (1994). Fiction of the contemporary south. Athens, Georgia, \& London: The University of Georgia Press.

Walker, A. (1983a). The color purple. London: Woman's Press.

Walker, A. (1983b). In search of our mother's gardens: Womanist prose. New York: Harcourt Brace Jovanovich.

Washington, M. H. (1979). An essay on Alice Walker. In H. L. Gates Jr. (Ed.), Alice Walker: Critical perspectives past and present. New York: Amistad.

Woodward, K. (2002). Understanding identity. London: Oxford University Press Inc.. 